(c) Group of authors, 2017

UDC 61:542.978:575.74

DOI - https://doi.org/10.14300/mnnc.2017.12090

ISSN - 2073-8137

\title{
STUDYING THE GEROPROTECTIVE EFFECTS OF INHIBITORS SUPPRESSING AGING-ASSOCIATED SIGNALING CASCADES IN MODEL ORGANISMS
}

\author{
Moskalev A. A. 1, 2, 3, 4 , Shaposhnikov M. V. ${ }^{2}$, Solovev I. A. ${ }^{2,4}$ \\ ${ }^{1}$ Engelhardt Institute of Molecular Biology, Russian Academy of Sciences, Moscow, \\ Russian Federation \\ 2 Institute of Biology of Komi Science Center of Ural Branch of Russian Academy \\ of Sciences, Sykłyvkar, Russian Federation \\ 3 Moscow Institute of Physics and Technology, Dolgoprudny, Russian Federation \\ ${ }^{4}$ Institute of Natural Sciences, Syktyvkar State University, Russian Federation
}

\section{ИССАЕАОВАНИЕ ГЕРОПРОТЕКТОРНЫХ СВОЙСТВ ИНГИБИТОРОВ АКТИВНОСТИ СВЯЗАННЫХ СО СТАРЕНИЕМ СИГНААЬНЫХ KAСКААОВ НА МОАЕАЬНЫХ ОРГАНИЗМАХ}

\author{
А. А. Москалев $1,2,3,4$, М. В. Шапошников ${ }^{2}$, И. А. Соловьёв 2,4 \\ ${ }^{1}$ Институт молекулярной биологии им. В. А. ЭнгельгарАта РАН, Москва, \\ Российская Фелерация \\ 2 Институт биологии Коми научного центра Уральского отАеления РАН, Сыктывкар, \\ Российская ФеАерация \\ ${ }^{3}$ Московский физико-технический институт, Аолгопруаный, Российская ФеАерация \\ ${ }^{4}$ Сыктывкарский госуаарственный университет им. Питирима Сорокина, \\ Российская ФеАерация
}

According to DrugAge (http://genomics.senescence.info/drugs/) and Geroprotectors.org (http://geroprotectors.org/) databases nowadays more than 200 compounds which elongate lifespan of model organisms exist. One of the most promising approaches constitutes aging-associated pathways (insulin/IGF-1, mTOR, NF- $k B$, PI3k, etc.) as main targets for new perspective geroprotectors' screening. In the current review we summarized the data touching upon geroprotectors that target signaling pathways which are involved in stress-response, metabolism, growth and proliferation, inflammation, apoptosis, etc. Some our results on Drosophila melanogaster and Caenorhabditis elegans models confirm the effectiveness of pathways of aging inhibition approach to the search for new geroprotectors.

Keywords: longevity, aging, geroprotector, signaling cascades pathways, model organisms

Согласно базам данных DrugAge (http://genomics.senescence.info/drugs/) и Geroprotectors.org (http:// geroprotectors.org/) на сегодня известно более 200 соединений, увеличивающих продолжительность жизни модельных организмов. Одним из многообещающих экспериментальных подходов для поиска новых эффективных геропротекторных средств может быть скрининг соединений, мишенями которых являются белки, участвующие в старение-ассоциированных сигнальных путях (инсулин/IGF-1, mTOR, NF-кB, PI3k и др.). B настоящем обзоре обобщены сведения о геропротекторах, модулирующих активность внутриклеточных сигнальных путей, вовлеченных в стресс-ответ, обмен веществ, рост клеток и организма, воспаление, апоптоз и др. Рассмотрены данные литературы и результаты собственных исследований по использованию таргетного подхода на примере моделей Drosophila melanogaster и Caenorhabditis elegans.

Ключевые слова: долголетие, старение, геропротекторы, сигнальные каскады, модельные организмы

he studies in model organisms such as budding yeast Saccharomyces cerevisiae, soil roundworm (nematode) Caenorhabditis elegans, fruit fly Drosophila melanogaster, and house mouse Musmusculus have established that longevity is genetically controlled. According to GenAge database there are about 2000 genes associated with aging and longevity in model organisms [58]. Mutations of pro-aging genes lead to substantial life extension in yeast, nematode, fruit fly, and house mouse (Table 1). Over expression of pro-longevity genes demonstrates the same effects on lifespan [47]. Though, manipulations with human hereditary apparatus are not possible now, this fact results in the search of alternative approaches to health span and lifespan extension. 
The list of maximum effects observed on model organisms (top mutations in pro-aging genes and experimental overexpression of anti-aging genes)

\begin{tabular}{|c|c|c|c|}
\hline $\begin{array}{l}\text { Model } \\
\text { organism }\end{array}$ & $\begin{array}{c}\text { Geneproduct } \\
\text { (signaling pathway) }\end{array}$ & \begin{tabular}{|l|} 
Life span \\
exten- \\
sion
\end{tabular} & $\begin{array}{l}\text { Refe- } \\
\text { rences }\end{array}$ \\
\hline \multicolumn{4}{|c|}{ Mutations } \\
\hline $\begin{array}{l}\text { Budding } \\
\text { yeast } \\
\text { Saccharo- } \\
\text { myces } \\
\text { cerevisiae }\end{array}$ & $\begin{array}{l}\text { Double mutant of RAS2 } \\
\text { (Ras/cAMP/PKA/Rim15/ } \\
\text { Msn2/4) and SCH9 } \\
\text { (Tor/Sch9/Rim15/Gis1) }\end{array}$ & \begin{tabular}{|l}
$10-$ fold \\
(M and \\
Max, in \\
combina- \\
tion with \\
calorie \\
restric- \\
tion)
\end{tabular} & {$[57]$} \\
\hline $\begin{array}{l}\text { Nematode } \\
\text { Caenorhab- } \\
\text { ditis } \\
\text { elegans }\end{array}$ & $\begin{array}{l}\text { AGE-1/PI3K } \text { CS (silences } \\
\text { multiple signaling path- } \\
\text { ways partially mediated } \\
\text { by the DAF-16/FOXO } \\
\text { transcription factor) }\end{array}$ & $\begin{array}{l}\text { 10-fold } \\
\text { (M and } \\
\text { Max) }\end{array}$ & $\begin{array}{l}{[2,} \\
52]\end{array}$ \\
\hline $\begin{array}{l}\text { Fruitfly } \\
\text { Drosophil- } \\
\text { amelano- } \\
\text { gaster }\end{array}$ & $\begin{array}{l}\text { INDY/SLC13A5 (trans- } \\
\text { porter of Krebs cycle } \\
\text { intermediates with } \\
\text { the highest affinity for } \\
\text { citrate) }\end{array}$ & $\begin{array}{l}1.8 \text {-fold } \\
\text { (M and } \\
\text { Max) }\end{array}$ & [49] \\
\hline $\begin{array}{l}\text { House } \\
\text { mouse } \\
\text { Musmusculus }\end{array}$ & $\begin{array}{l}\text { Prop-1 (control of ad- } \\
\text { enohypophyseal devel- } \\
\text { opment) }\end{array}$ & $\begin{array}{l}1.6 \text {-fold } \\
\text { (M and } \\
\text { Max) }\end{array}$ & {$[6]$} \\
\hline \multicolumn{4}{|c|}{\begin{tabular}{|c|} 
Over expression \\
\end{tabular}} \\
\hline $\begin{array}{l}\text { Budding } \\
\text { yeast Sac- } \\
\text { charomyces } \\
\text { cerevisiae }\end{array}$ & $\begin{array}{l}\text { MCA1, } \mathrm{Ca}^{2+} \text {-dependent } \\
\text { cysteine protease } \\
\text { (proteostatic stress) }\end{array}$ & $56 \%(\mathrm{M})$ & {$[25]$} \\
\hline $\begin{array}{l}\text { Nematode } \\
\text { Caenor- } \\
\text { habditis } \\
\text { elegans }\end{array}$ & $\begin{array}{l}\text { TKR-1, tyrosine kinase } \\
\text { receptor-1 (activation } \\
\text { of the DAF-16/FOXO } \\
\text { transcription factor) } \\
\end{array}$ & $\begin{array}{l}65 \%(\mathrm{M} \\
\text { and Max) }\end{array}$ & {$[43]$} \\
\hline $\begin{array}{l}\text { Fruitfly } \\
\text { Drosophila } \\
\text { melano- } \\
\text { gaster }\end{array}$ & $\begin{array}{l}\text { D-GADD45 } \\
\text { (DNA-damage } \\
\text { response) }\end{array}$ & $\begin{array}{l}102 \% \\
(\mathrm{M}) \\
50 \% \\
(\mathrm{Max}) \\
\end{array}$ & {$[45]$} \\
\hline $\begin{array}{l}\text { House } \\
\text { mouse } \\
\text { Musmusculus }\end{array}$ & $\begin{array}{l}\text { hNAG-1/hGDF15 } \\
\text { (energy metabolism } \\
\text { and insulin/IGF-1/mTOR } \\
\text { signaling) }\end{array}$ & $43 \%(M)$ & {$[55]$} \\
\hline
\end{tabular}

The note: $\mathrm{M}$ - median lifespan; Max - maximum lifespan.

Pharmaceutical impact on longevity- and aging-associated gene products allows one to increase the lifespan of model organisms without DNA editing, which opens it for use on humans. To date there is an opportunity to select the pharmacological inhibitors for pro-aging factors and also it is possible to sort out the inhibitors which activate expression of pro-longevity genes by suppression of its negative regulators. So-called «target approach» is probably the syntheses of the genetics of aging and longevity, modern drug design and advances in translational medicine (using model organisms) [37].

The pharmacological agents that decrease the rate of aging and extend lifespan are called geroprotectors [3638]. The term «geroprotector» (literally «protecting from aging") was first coined by the Nobel Prize laureate Ilya Mechnikov, an outstanding Russian and French scientist, in 1910 [35], but those times the concept had not been widely used before enough empirical data was accumulated. First attempts of life extension via pharmacological treatment were described in the pioneer investigations of Thomas Gardner experiments performed on mice $[15,18]$ and on flies $[16,17]$ in 1940s. The elevation of researchers' interest to anti-aging drugs took place in 1960s, which was connected to endeavours of «Free Radical Theory of Aging" (by Denham Harman [21]) evaluation, as well as with discovery of phenomenon of longevity hormesis [44]. At the present day, according to Geroprotectors.org (http://geroprotectors.org/) [36] and DrugAge (http:// genomics.senescence.info/drugs/) [4] databases, found more than 200 geroprotectors. However the lifespan-extending effects of pharmacological interventions surpass the threshold of $20-40 \%$ very seldom, mutations of aging genes and over expression of longevity genes usually have more significant impact. The increment of median lifespan often depends on model complexity; the simplest model shows typically great effects (Table 2 ).

Table 2

Lifespan-extending effects of rapamycin (mTOR inhibitor) in different model organisms

\begin{tabular}{|l|c|c|}
\hline \multicolumn{1}{|c|}{ Model organism } & $\begin{array}{c}\text { Life span } \\
\text { extension }\end{array}$ & References \\
\hline $\begin{array}{l}\text { Budding yeast } \\
\text { Saccharomyces cerevisiae }\end{array}$ & $\begin{array}{l}100 \% \\
\text { (M and Max) }\end{array}$ & {$[46]$} \\
\hline $\begin{array}{l}\text { Nematode Caenorhabditis } \\
\text { elegans }\end{array}$ & $\begin{array}{c}20 \% \\
\text { and Max })\end{array}$ & {$[48]$} \\
\hline $\begin{array}{l}\text { Fruitfly Drosophila } \\
\text { melanogaster }\end{array}$ & $\begin{array}{c}5 \% \\
(\mathrm{M})\end{array}$ & {$[41]$} \\
\hline $\begin{array}{l}\text { House mouse } \\
\text { Musmusculus }\end{array}$ & $\begin{array}{c}60 \% \\
(\mathrm{M})\end{array}$ & {$[8]$} \\
\hline
\end{tabular}

The note: $\mathrm{M}$ - median lifespan; Max - maximum lifespan.

Recently, the system of criteria for geroprotector identification and classification were proposed [37, 38]. The main criteria are (1) the ability to prolong life, in addition, a potential geroprotector should (2) return the biomarkers of aging to the state characteristic of a young organism; (3) the dose providing effective use must be fundamentally lower than the toxic dose with (4) minimal side effects at therapeutic dosage, and, finally, (5) the quality of life in patients treating with geroprotectors should increase, and the physical, mental, emotional state should improve. Secondary criteria are worthy of mention either: (1) the geroprotector should be aimed at evolutionarily conservative targets; (2) the hormetic effect must, in consequence, be reproduced on different models, despite the likely absence of a specific target; (3) the potential geroprotector is obliged to reduce the rate of development of age-related pathologies and (4) has to increase resistance to environmental challenges.

Taking into account the existence of compounds which extend lifespan of model organisms, we have to admit that in most cases a specific mechanism has not been clarified, so the concrete target is typically unknown or there is a wide variety of targets impacted by the chemical. Target approach is an alternative to non specialized methods of aging therapy.

The target approach. The products of genes that affect longevity and aging represent potential targets for pharmacological intervention [9, 37]. The candidate geroprotectors may be selected from a libraries of natural and synthetic compounds or discovered by computerassisted molecular design approaches [22]. The main advantage of the drug design approach is an extensive toolkit, allowing to conduct a theoretical selection of compounds that can affect the molecule of interest. Thus, online services and commercial packages that carry out molecular docking through a wide range of mathematical methods are widely spread [7, 19, 31, 34]. Another powerful tool for anti-aging therapy selection is a set of algorithms that implement machine learning on big data [5]. 
The goal of target approach is in simplified experimental design, which implies the formula «one drug - one target - one mechanism» [33]. The specific inhibitors of PI3K (LY-294002 and wortmannin) and TOR (rapamycin) kinases, pro-inflammatory transcription factor NF-kB (pyrrolidindithiocarbamate and QNZ), and inducible NO synthase iNOS (1400W) have been shown to increase Drosophila lifespan [11, 39, 42]. High specificity of small molecules is rather rear in pharmacology, thus, the observed effects could be determined by the interaction with the target of interest. The genuine high affinity and specificity may be only reached after numerous changes have been made in the molecule design. However, safety and bioavailability of the hypothetical compound cannot be guaranteed. The shortcomings of the target approach undoubtedly include its application to the most part of approved pharmaceuticals, so far as the list of each potential targets is long [50].

It is worth noting that there are revolutionary inhibitors which have an ultimate affinity to its targets, the majority of these drugs are antibodies and nanoantibodies, unfortunately, and the usage is limited by the size. The smallest antibodies are able to inhibit only targets on the cell membrane [54]. However recently presented modular strategy enables to create functional cell-permeable nanobodies capable of targeted manipulation of intracellular antigens in living cells [24]

Using traditional method "one drug - one target» it is difficult to observe an outstanding lifespan extension effect with a single geroprotector. The aging is multifactorial process involving a complex interplay of individual proteins and entire signaling pathways [40]. In the light of low efficacy of monotherapy of aging in model animals, researhers are interested in synergistic effects of combined inhibitors targeting multiple components within the different signaling pathways (Table 3 ). The drugs that interact with multiple targets might give better results also [53]. The increasing of molecular specificity of compounds might reduce the side effects of potential geroprotectors.

Pharmaceutical targeting of aging-associated signaling pathways. Model organisms have been used not only to identify individual aging genes and proteins related to ageing and longevity but also entire signal transduction pathways, that are known to be evolutionary conserved from invertebrate to mammals. The following signaling pathways are involved in regulating the aging process: insulin/IGF-1, PI3K, TOR, MAPK, AMPK, PKC, NF- $\kappa B$, TGF- $\beta$, Notch, and WNT [40]. Under favorable environmental conditions, these signaling cascades control energy balance, cellular plasticity, and the mechanisms supporting homeostasis, growth, and reproduction. However, under harmful conditions, the hormonal stimulation of growth is blocked, while stress-resistance proteins are activated. Number of known geroprotectors can stimulate stress-resistance and promote longevity via mechanisms of hormesis [44]. Among them both natural products and man-made drugs may be found [14, 29, 36]. For example in Drosophila the lifespan-extending effect of the low methyl esterified pectins is mediated by intracellular pathways that involve NF- $\kappa B$ signaling and activation of stress response genes including DNA repair (D-GADD45, mei-9, spn-B), apoptosis (wrinkled/ hid), and heat shock response (hsp70Aa) genes [51]. Carotenoid fucoxanthin increases lifespan in Drosophila melanogaster and Caenorhabditis elegans and upregulates the expression of stress response genes involved in oxidative stress (sod1, Keap1, CncC/Nrf2, GclC), DNA repair (D-GADD45, mei-9, spn-B, p53), heat shock response ( $h s p 70 A a)$, and some longevity-associated genes (dSir2/SIRT1 and JNK) [30]. Enhanced longevity by non-steroidal anti-inflammatory drugs in multiple species (Saccharomyces cerevisiae, Caenorhabditis elegans and Drosophila melanogaster) may occurs through inhibition of Tat2p, a known target of TOR involved in tryptophan import in the cells $[12,23]$. Thus the one more promising approach for development a new geroprotectors may be the screening of compound libraries on chemicals with the ability to activate stress response pathways.

Table 3

\begin{tabular}{|c|c|c|c|c|}
\hline \multicolumn{5}{|c|}{ creasing lifespar } \\
\hline $\begin{array}{l}\text { Model organ- } \\
\text { ism }\end{array}$ & $\begin{array}{c}\text { Combina- } \\
\text { tion of } \\
\text { geropro- } \\
\text { tectors }\end{array}$ & $\begin{array}{l}\text { Targets (sig- } \\
\text { naling path- } \\
\text { ways) }\end{array}$ & \begin{tabular}{|c|} 
Life \\
span \\
exten- \\
sion
\end{tabular} & $\begin{array}{l}\text { Refer- } \\
\text { ences }\end{array}$ \\
\hline $\begin{array}{l}\text { Budding } \\
\text { yeast Sac- } \\
\text { charomyces- } \\
\text { cerevisiae }\end{array}$ & $\begin{array}{l}\text { Rapamy- } \\
\text { cin and } \\
\text { myriocin }\end{array}$ & $\begin{array}{l}\text { Tor (Tor/ } \\
\text { Sch9/ } \\
\text { Rim15/Gis1) } \\
\text { and Pkh1/2 } \\
\text { (sphingolip- } \\
\text { id/Pkh1/2/ } \\
\text { Sch9) }\end{array}$ & \begin{tabular}{|l}
2.4 fold \\
(M and \\
Max)
\end{tabular} & {$[28]$} \\
\hline $\begin{array}{l}\text { Fission yeast } \\
\text { Schizosac- } \\
\text { charomyces } \\
\text { pombe }\end{array}$ & $\begin{array}{l}\text { Rapamy- } \\
\text { cin and } \\
\text { myriocin }\end{array}$ & $\begin{array}{l}\text { Tor (Tor/ } \\
\text { Sch9/ } \\
\text { Rim15/Gis1) } \\
\text { and Pkh1/2 } \\
\text { (sphingolip- } \\
\text { id/Pkh1/2/ } \\
\text { Sch9) }\end{array}$ & \begin{tabular}{|c|}
9.6 fold \\
(M and \\
Max)
\end{tabular} & [27] \\
\hline $\begin{array}{l}\text { Nematode } \\
\text { Caenorhab- } \\
\text { ditis elegans }\end{array}$ & \begin{tabular}{|l|} 
Rapamy- \\
cin, rifam- \\
picin, an- \\
dallantoin
\end{tabular} & $\begin{array}{l}\text { TOR (TOR/ } \\
\text { S6K/4E-BP), } \\
\text { JNK (JNK-1/ } \\
\text { DAF-16), } \\
\text { and calorie } \\
\text { restriction } \\
\text { mimetic } \\
\end{array}$ & $\begin{array}{c}96.6 \% \\
(\mathrm{~A}) \\
76.3 \% \\
(\mathrm{Max})\end{array}$ & [13] \\
\hline $\begin{array}{l}\text { Nematode } \\
\text { Caenorhab- } \\
\text { ditis elegans }\end{array}$ & \begin{tabular}{|l|} 
Rifam- \\
picin, \\
Psora-4, \\
andallan- \\
toin
\end{tabular} & $\begin{array}{l}\text { TOR (TOR/ } \\
\text { S6K/4E-BP), } \\
\text { K-channel, } \\
\text { and calorie } \\
\text { restriction } \\
\text { mimetic }\end{array}$ & $\begin{array}{c}89.5 \% \\
(\mathrm{~A}) \\
76.1 \% \\
(\text { Max) }\end{array}$ & [13] \\
\hline $\begin{array}{l}\text { Fruitfly Dro- } \\
\text { sophilam } \\
\text { elanogaster }\end{array}$ & \begin{tabular}{|l|} 
Rapamycin \\
and wort- \\
mannin
\end{tabular} & $\begin{array}{l}\text { Tor (Tor/ } \\
\text { S6K/4E-BP) } \\
\text { and PI3K } \\
\text { (PI3K/AKT/ } \\
\text { FOXO) }\end{array}$ & $\begin{array}{c}14.6 \% \\
(\mathrm{M}) \% \\
23.4 \% \\
(\mathrm{Max})\end{array}$ & [11] \\
\hline
\end{tabular}

The note: A - average lifespan; $\mathrm{M}$ - median lifespan; Max maximum lifespan.

The current progresses in pharmacological correction of aging-associated signaling pathways to increase lifespan are presented in figure. However particular signaling pathways (for example, WNT and Notch) are involved in a very complex network of pathways and have pleiotropic effects on longevity, and it is difficult to apply the pharmacological approach for correction of their activity for lifespan increase [3, 20].

Using the groups of geroprotectors or multitarget drugs provide a new opportunity for inhibition of critical links that allow the functioning of the extensive pathological processes associated with aging, for example inflammation $[32,56]$. It is also proposed to compare the signaling pathways activated in the course of aging with pathways active in cancer, due to the presence of similarities between the lists of genes and participating proteins. Aging/Cancer pathways may be targeted by precise anticancer drugs [26]. Another powerful approach is to use computational tools to carry out signaling pathway analysis of gene expression between young and old cells. Based on the signaling pathway results, known compounds may be screened and 


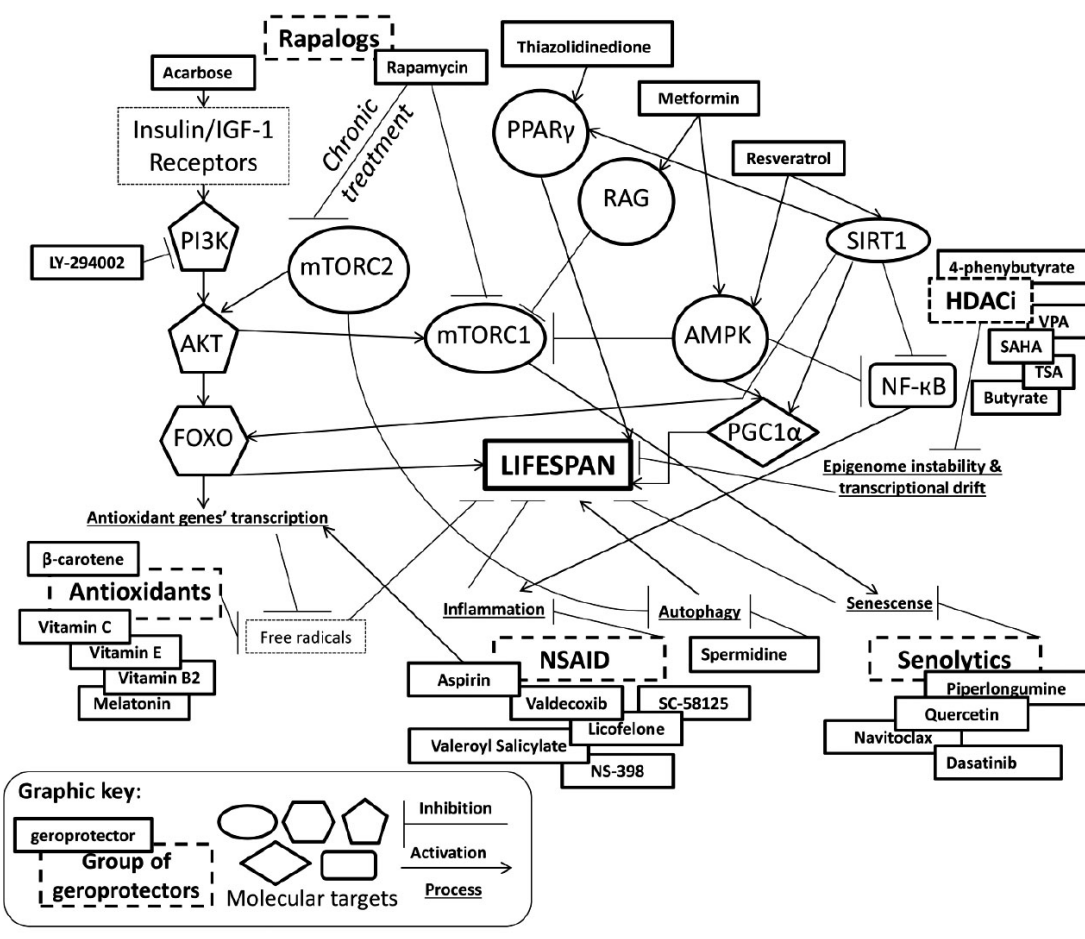

Fig. The integral scheme of anti-aging treatment has lifespan in its core, the most studied and perspective pathways and processes to be inhibited or activated lay around the central node. In the outer circle you see the pharmacological groups of drugs and compound which form these groups. The scheme is based on materials of DrugAge (http://genomics.senescence.info/ drugs/) [4] and Geroprotectors.org (http://geroprotectors.org/) [36] databases

to aspects of design, combination and evaluation of geroprotectors and complex geroprotector therapies. [10].

Thus, the usage of drugs targeting aging-associated pathways makes the synergistic effect on lifespan of model organisms possible.

Conclusions. Notwithstanding the 70 years of research history, geroprotectors significantly pass up genetic approaches. The search of compounds having high geroprotective activity is one of the hottest issues of contemporary biogerontology and medicine. Using the target approach it is possible to boost the specificity of geroprotectors to their molecular targets and improve the particular effects. Considering the multifactorial origin of aging the combinations of different specific inhibitors as well as multitarget drugs have to be used.

The computer-assisted molecular design approaches will play a growing role in the discovery of new geroprotectors. A new opportunity for predicting lifespan-extending chemical compounds provides the using of a computational tools and predictive machine learning methods $[1,5]$.

Using of lifespan-extending compounds for a long time and even throughout the whole lifetime can dramatically increase the risk of side effects. Recent studies in mice suggests

ranked, in order to identify the best compounds to target those pathways and restore a «young» cellular profile [1]. Using this approach six substances, that demonstrate lifespan-extending effects in animal models, were tested for geroprotective effects in senescent human fibroblast cultures. PD-98059, a highly selective MEK1 inhibitor, showed both life-prolonging and rejuvenating effects. Natural compounds like N-acetyl-L-cysteine, Myricetin and Epigallocatechin gallate also improved several senescence-associated properties [1].

However, there is a concept which stands apart, Mikhail Blagosklonny suggests to concentrate the attention on mTOR signaling pathway and inhibit it using rapalogs. When a stable effect is obtained it is suggested to use IGF targeting drugs, angiotensin 2 blockers, betaadrenoblockers, statins, COX-2 inhibitors, PDE5 inhibitors either. In addition, he proposes the development of antiaging pharmaceutics that implies a systemic approach

\section{References}

1. Aliper A., Belikov A. V., Garazha A. [et al.] In search for geroprotectors: in silico screening and in vitro validation of signalome-level mimetics of young healthy state. Aging (Albany NY). 2016;8(9):2127-2152. doi: 10.18632/aging. 101047

2. Ayyadevara S., Alla R., Thaden J. J., Shmookler Reis R. J. Remarkable longevity and stress resistance of nematode PI3K-null mutants. Aging Cell. 2008;7(1):1322. doi: $10.1111 / \mathrm{j} .1474-9726.2007 .00348 . x$

3. Balistreri C. R., Madonna R., Melino G., Caruso C. The emerging role of Notch pathway in ageing: Focus on the related mechanisms in age-related diseases. Ageing Res Rev. 2016;29:50-65. doi: 10.1016/j.arr.2016.06.004

4. Barardo D., Thornton D., Thoppil H. [et al.] The DrugAge database of aging-related drugs. Aging Cell. 2017;16(3):594-597. doi: 10.1111/acel.12585 that reduction in side effects can be achieved by shortterm treatment, which is sufficient to increase life expectancy but is insufficient for development of adverse effects [8].

Eventually the development of new highly effective geroprotectors with using the model organisms will give the opportunity to slow down ageing, postpone onset of age-related diseases, and increase the maximum lifespan in human.

Acknowledgments. The study was carried out within the framework of the state task on themes «Moleculargenetic mechanisms of interrelations between stress tolerance and lifespan on the example of Drosophila melanogaster» state registration №115012130067 and «Ecological genetics, transcriptomics and metabolomics of lifespan and stress resistance of 13 species from Drosophila genus. Complex UrB RAS Programme» № 154-4-23, state registration №115082010010.

5. Barardo D. G., Newby D., Thornton D. [et al.] Machine learning for predicting lifespan-extending chemical compounds. Aging (Albany NY). 2017;9(7):1721-1737. doi: 10.18632/aging.101264

6. Bartke A., Brown-Borg H. Life extension in the dwarf mouse. Curr. Top. Dev. Biol. 2004;63:189-225. doi: 10.1016/S0070-2153(04)63006-7

7. Bikadi Z., Hazai E. Application of the PM6 semi-empirical method to modeling proteins enhances docking accuracy of AutoDock. J. Cheminform. 2009;1:15. doi: 10.1186/1758-2946-1-15

8. Bitto A., Ito T. K., Pineda V. V. [et al.] Transient rapamycin treatment can increase lifespan and healthspan in middle-aged mice. Elife. 2016;5. doi: 10.7554/ eLife. 16351

9. Blagosklonny M. V. An anti-aging drug today: from senescence-promoting genes to anti-aging pill. Drug 
Discov. Today. 2007;12(5-6):218-224. doi: 10.1016/j. drudis.2007.01.004

10. Blagosklonny M. V. From rapalogs to anti-aging formula. Oncotarget. 2017;8(22):35492-35507. doi: 10.18632/ oncotarget 18033

11. Danilov A., Shaposhnikov M., Plyusnina E. [et al.] Selective anticancer agents suppress aging in Drosophila. Oncotarget. 2013;4(9):1507-1526. doi: 10.18632 /oncotarget1272

12. Danilov A., Shaposhnikov M., Shevchenko O. [et al.] Influence of non-steroidal anti-inflammatory drugs on Drosophila melanogaster longevity. Oncotarget. 2015;6(23):19428-19444. doi: 10.18632/oncotarget5118

13. Dessale T., Batchu K. C., Barardo D. [et al.] Slowing ageing using drug synergy in C. elegans. bioRxiv. 2017. doi: $10.1101 / 153205$

14. Fomenko A. N., Proshkina E. N., Fedintsev A. Y. [et al.] Potential geroprotectors. - Sankt-Peterburg, 2016.

15. Gardner T. S. The effect of yeast nucleic acid on the survival time of 600 day old albino mice. Journal of Gerontology. 1946;1(Pt 1 4):445-452. doi: 10.1093/ geronj/1.4_Part_2.205

16. Gardner T. S. The use of Drosophila melanogaster as a screening agent for longevity factors: II. The effects of biotin, pyridoxine, sodium yeast nucleate, and pantothenic acid on the life span of the fruit fly. Journal of Gerontology. 1948;3(1):9-13. doi: 10.1093/ geronj/3.1.9

17. Gardner T. S. The use of Drosophila melanogaster as a screening agent for longevity factors; pantothenic acid as a longevity factor in royal jelly. Journal of Gerontology. 1948;3(1):1-8. doi: 10.1093/geronj/3.1.1

18. Gardner T. S., Forbes F. B. The effect of sodium thiocyanate and yeast nucleic acid on the survival time of 700 day old albino mice. Journal of Gerontology. 1946;1(Pt 1 4):453-456. doi: 10.1093/geronj/1.4 Part_2.209

19. Grosdidier A., Zoete V., Michielin O SwissDock, a protein-small molecule docking web service based on EADock DSS. Nucleic Acids Res. 2011;39(Web Server issue):W270-277. doi: $10.1093 /$ nar/gkr366

20. Gruber J., Yee Z., Tolwinski N. Developmental Drift and the Role of Wnt Signaling in Aging. Cancers. 2016;8(8):73. doi: $10.3390 /$ cancers 8080073

21. Harman D. Aging: a theory based on free radical and radiation chemistry. J. Gerontol. 1956;11(3):298-300. doi: 10.1093/geronj/11.3.298

22. Hartenfeller M., Schneider G. De novo drug design. Methods Mol. Biol. 2011;672:299-323. doi: 10.1007/978-1-60761-839-3_12

23. He C., Tsuchiyama S. K., Nguyen Q. T., Plyusnina E. N. [et al.] Enhanced longevity by ibuprofen, conserved in multiple species, occurs in yeast through inhibition of tryptophan import. PLoS Genet. 2014;10(12):e1004860. doi: 10.1371 /journal.pgen. 1004860

24. Herce H. D., Schumacher D., Schneider A. F. L. [et al.] Cell-permeable nanobodies for targeted immunolabelling and antigen manipulation in living cells. Nat. Chem. 2017;9(8):762-771. doi: 10.1038/ nchem. 2811

25. Hill S. M., Hao X., Liu B., Nystrom T. Life-span extension by a metacaspase in the yeast Saccharomyces cerevisiae. Science. 2014;344(6190):1389-1392. doi: 10.1126/science.1252634

26. Honoki K., Fujii H., Tsukamoto S. [et al.] Crossroads of hallmarks in aging and cancer: Anti-aging and anticancer target pathways can be shared. Trends in Cancer Research. 2016;11:39-59.

27. Huang X., Leggas M., Dickson R. C. Drug synergy drives conserved pathways to increase fission yeast lifespan. PLOS ONE. 2015;10(3):e0121877. doi: 10.1371/journal. pone. 0121877

28. Huang X., Liu J., Withers B. R. [et al.] Reducing signs of aging and increasing lifespan by drug synergy. Aging Cell. 2013;12(4):652-660. doi: 10.1111/acel.12090

29. Huhne R., Thalheim T., Suhnel J. AgeFactDB - the JenAge Ageing Factor Database - towards data integration in ageing research. Nucleic Acids Res. 2014;42(Database issue):D892-896. doi: 10.1093/nar/gkt1073

30. Lashmanova E., Proshkina E., Zhikrivetskaya S. [et al.] Fucoxanthin increases lifespan of Drosophila melanogaster and Caenorhabditis elegans. Pharmacol. Res. 2015;100:228-241. doi: 10.1016/j.phrs.2015.08.009
31. Liao C., Sitzmann M., Pugliese A., Nicklaus M. C. Software and resources for computational medicinal chemistry. Future Med. Chem. 2011;3(8):1057-1085. doi: $10.4155 /$ fmc. 11.63

32. López-Otín C., Blasco M. A., Partridge L. [et al.] The hallmarks of aging. Cell. 2013;153(6):1194-1217. doi: 10.1016/j.cell.2013.05.039

33. Medina-Franco J. L., Giulianotti M. A., Welmaker G. S., Houghten R. A. Shifting from the single to the multitarget paradigm in drug discovery. Drug Discov. Today. 2013;18(9-10):495-501. doi: 10.1016/j. drudis.2013.01.008

34. Meng X. Y., Zhang H. X., Mezei M., Cui M. Molecular docking: a powerful approach for structure-based drug discovery. Curr. Comput. Aided. Drug Des. 2011;7(2): 146-157. doi: $10.2174 / 157340911795677602$

35. Metchnikoff E., Mitchell P. C. The prolongation of life: optimistic studies. - New York \& London: G. P. Putnam's Sons, 1910.

36. Moskalev A., Chernyagina E., de Magalhaes J. P. [et al.] Geroprotectors.org: a new, structured and curated database of current therapeutic interventions in aging and age-related disease. Aging (Albany NY). 2015;7(9):616-628. doi: 10.18632/aging.100799

37. Moskalev A., Chernyagina E., Kudryavtseva A., Shaposhnikov M. Geroprotectors: A Unified Concept and Screening Approaches. Aging Dis. 2017;8(3):354-363. doi: 10.14336/AD.2016.1022

38. Moskalev A., Chernyagina E., Tsvetkov V. [et al.] Developing criteria for evaluation of geroprotectors as a key stage toward translation to the clinic. Aging Cell. 2016;15(3):407-415. doi: 10.1111/acel.12463

39. Moskalev A., Shaposhnikov M. Pharmacological inhibition of NF-kB prolongs lifespan of Drosophila melanogaster. Aging (Albany NY). 2011;3(4):391-394. doi: 10.18632/aging.100314

40. Moskalev A. A., Aliper A. M., Smit-McBride Z. [et al.] Genetics and epigenetics of aging and longevity. Cell. Cycle. 2014;13(7):1063-1077. doi: 10.4161/cc.28433

41. Moskalev A. A., Shaposhnikov M. V. Pharmacological inhibition of phosphoinositide 3 and TOR kinases improves survival of Drosophila melanogaster. Rejuvenation Res. 2010;13(2-3):246-247. doi: 10.1089/ rej.2009.0903

42. Moskalev A. A., Shaposhnikov M. V. Pharmacological inhibition of phosphoinositide 3 and TOR kinases improves survival of Drosophila melanogaster. Rejuvenation Res. 2010;13(2-3):246-247. doi: 10.1089/rej.2009.0903

43. Murakami S., Johnson T. E. Life extension and stress resistance in Caenorhabditis elegans modulated by the tkr-1 gene. Curr Biol. 1998;8(19):1091-1094. doi: 10.1016/S0960-9822(98)70448-8

44. Neafsey P. J. Longevity hormesis. A review. Mech Ageing Dev. 1990;51(1):1-31. doi: 10.1016/00476374(90)90158-C

45. Plyusnina E. N., Shaposhnikov M. V., Moskalev A. A. Increase of Drosophila melanogaster lifespan due to $D-G A D D 45$ overexpression in the nervous system. Biogerontology. 2011;12(3):211-226. doi: 10.1007/ s10522-010-9311-6

46. Powers R. W., Kaeberlein M., Caldwell S. D. [et al.] Extension of chronological life span in yeast by decreased TOR pathway signaling. Genes. Dev. 2006;20(2):174184. doi: $10.1101 / \mathrm{gad} .1381406$

47. Proshkina E. N., Shaposhnikov M. V., Sadritdinova A. F. [et al.] Basic mechanisms of longevity: A case study of Drosophila pro-longevity genes. Ageing Res. Rev. 2015;24(Pt B):218-231. doi: 10.1016/j.arr.2015.08.005

48. Robida-Stubbs S., Glover-Cutter K., Lamming D. W. [et al.] TOR signaling and rapamycin influence longevity by regulating SKN-1/Nrf and DAF-16/FoxO. Cell. Metab. 2012;15(5):713-724. doi: 10.1016/j.cmet2012.04.007

49. Rogina B., Reenan R. A., Nilsen S. P., Helfand S. L. Extended life-span conferred by cotransporter gene mutations in Drosophila. Science. 2000;290(5499):21372140. doi: $10.1126 /$ science.290.5499.2137

50. Schmidt F., Matter H., Hessler G., Czich A. Predictive in silico off-target profiling in drug discovery. Future Med. Chem. 2014;6(3):295-317. doi: 10.4155/fmc.13.202

51. Shaposhnikov M., Latkin D., Plyusnina E. [et al.] The effects of pectins on life span and stress resistance in Drosophila melanogaster. Biogerontology. 2014; 15(2): 113-127. doi: 10.1007/s10522-013-9484-x 
52. Shmookler Reis R. J., Bharill P., Tazearslan C., Ayyadevara $S$. Extreme-longevity mutations orchestrate silencing of multiple signaling pathways. Biochim Biophys Acta. 2009;1790(10):1075-1083. doi: 10.1016/j. bbagen.2009.05.011

53. Simko G. I., Gyurko D., Veres D. V. [et al.] Network strategies to understand the aging process and help age-related drug design. Genome Med. 2009;1(9):90. doi: $10.1186 /$ gm90

54. Van Bockstaele F., Holz J. B., Revets H. The development of nanobodies for therapeutic applications. Curr Opin Investig Drugs. 2009;10(11):1212-1224. doi: 10.2217/ nnm.13.86

55. Wang X., Chrysovergis K., Kosak J. [et al.] hNAG-1 increases lifespan by regulating energy metabolism and insulin/IGF-1/mTOR signaling. Aging (Albany NY). 2014;6(8):690-704. doi: 10.18632/aging.100687

56. Wei D., Jiang X., Zhou L. [et al.] Discovery of multitarget inhibitors by combining molecular docking with common pharmacophore matching. J. Med. Chem. 2008;51(24):7882-7888. doi: 10.1021/jm8010096

57. Wei M., Fabrizio P., Hu J. [et al.] Life span extension by calorie restriction depends on Rim 15 and transcription factors downstream of Ras/PKA, Tor, and Sch9. PLoS Genet. 2008;4(1):e13. doi: 10.1371/journal. pgen.0040013

58. Yanai H., Budovsky A., Barzilay T. [et al.] Widescale comparative analysis of longevity genes and interventions. Aging Cell. 2017; doi: 10.1111/acel.12659

\title{
About authors:
}

Moskalev Alexey Alexandrovich, DBSc, RAS professor, correspondind member of RAS, Head of Department for Ecology, Head of Laboratory for Molecular Radiobiology and Gerontology; tel.: +78212312894; e-mail: amoskalev@ib.komisc.ru

Shaposhnikov Mikhail Vyacheslavovich, CBSc, Associate Professor of Department for Ecology; tel.: +78212312894; e-mail: shaposhnikov@ib.komisc.ru

Solovev Ilya Andreevich, Post-graduate student; tel.: +78212312894; e-mail: ilyasolovev-ksc@yandex.ru

\section{NITROUS OXIDE. SHOULD IT STILL BE USED IN PEDIATRIC MEDICINE? (PART 1)}

Booij L. H. D. Hj.

\author{
Radboud University Medical Centre, Nijmegen, The Netherlands
}

\section{ЗАКИСЬ АЗОТА. НУЖНА АИ ОНА НАМ ПРИ ПРОВЕАЕНИИ АНЕСТЕЗИИ У АЕТЕЙ? (ЧАСТЬ І)}

\section{^ео Бой}

\author{
МеАицинский Центр РаАбурАского Университета, Ниемеген, НиАерланаы
}

Nitrous oxide $\left(\mathrm{N}_{2} \mathrm{O}\right)$ has been used in medicine for more than 165 years. By incidence was the analgesic effect recognized by Howard Wells. Originally was it thought to be a clean and anesthetic not causing a single adverse effect, and therefore was it considered the safest anesthetic. However, around 1956 was it recognized that some patients, after prolonged exposure developed, mostly transient, megaloblastic anemia and neurological disorders. Gradually became adverse effects more known. This resulted in discussions in the literature on the safety of $\mathrm{N}_{2} \mathrm{O}$. Since the 1990 's are there indications that $\mathrm{N}_{2} \mathrm{O}$ administration in children during the period of brain development and in elderly persons has neurotoxic effects. This lead to the conclusion of many that $\mathrm{N}_{2} \mathrm{O}$ should no longer be used in medicine. However, other physicians have the opinion that there is no reason to stop the use of $\mathrm{N}_{2} \mathrm{O}$.

Keywords: pediatric anesthesia, children surgery, anesthesia associated complications in children, drugs adverse reactions

Закись азота $\left(\mathrm{N}_{2} \mathrm{O}\right)$ применяется в медицинских целях более 165 лет. Ее аналгетический эффект был случайно обнаружен Говардом Веллсом. Изначально считалось, что это достаточно безопасный анестетик, не вызывающий побочных реакций. Однако начиная с середины 1950-х годов было замечено, что у ряда пациентов, получавших этот анестетик, развивались преходящие неврологические расстройства и мегалобластическая анемия. Постепенно все большее количество побочных эффектов данного препарата было замечено при его практическом применении. В 1990-х годах было показано, что его использование у детей в период развития головного мозга, а также у пожилых пациентов приводит к развитию нейротоксических эффектов. Это привело к широкой дискуссии относительно использования закиси азота ввиду его небезопасности для пациентов и персонала, а также к заключению о нецелесообразности использования закиси азота. Однако не менее обширная когорта медицинских профессионалов не видит оснований для прекращения применения закиси азота в своей практике.

Ключевые слова: педиатрическая анестезия, детская хирургия, осложнения анестезии у детей, побочные эффекты лекарственных средств 